\title{
Relationship between annual rainfall and interception ratio for forests across Japan
}

\author{
Hikaru Komatsu*, Yoshinori Shinohara, Tomonori Kume, Kyoichi Otsuki \\ Kasuya Research Forest, Kyushu University, 394 Tsubakuro, Sasaguri, Kasuya, Fukuoka 811-2415, Japan
}

\section{A R T I C L E I N F O}

\section{Article history:}

Received 16 November 2007

Received in revised form 13 June 2008

Accepted 17 June 2008

\section{Keywords:}

Annual rainfall

Forest

Interception ratio

Japan

Rainfall interception

Regional variation

\begin{abstract}
A B S T R A C T
Several previous studies in Japan have examined differences in rainfall interception amounts induced by differences in forest properties by comparing the annual rainfall interception ratios (annual rainfall interception divided by annual rainfall) from various sites without considering variations in meteorological conditions between sites. Rainfall interception actually depends on meteorological conditions as well as forest properties. This study examined variations in the annual interception ratio relating to the variation in annual rainfall, which would be the primary factor relating to the interception ratio, across Japan with the use of a rainfall interception model assuming the same forest properties (i.e., the canopy storage capacity, canopy closure, leaf area index (LAI), and the bulk coefficient for sensible heat transfer). The ratio ranged between 0.12 and 0.24 across Japan and was highly correlated to annual rainfall. This indicates that considering the variation in annual rainfall is critical for assessing the difference in rainfall interception amounts induced by forest properties. We reconsidered the results of previous studies in Japan that compared annual interception ratios between sites with different forest properties: (i) there is no clear difference in interception amounts between broadleaf and coniferous forests and (ii) there is a positive correlation in stem density and interception amounts for coniferous forests. These results still held when considering differences in annual rainfall between sites.
\end{abstract}

(c) 2008 Elsevier B.V. All rights reserved.

\section{Introduction}

In Japan, forest covers most mountainous regions located upstream of agricultural and urban areas. Some researchers examined relationships of rainfall amounts with elevation in Japan based on GIS data (Sawano et al., 2005) and in situ gauge observations (Yamamura and Nakano, 1985; Yamada et al., 1995) and reported a positive correlation between them. (Similar results were also reported in other Asian monsoon regions (Dairaku et al., 2000, 2004; Kuraji et al., 2001)). Thus, forested areas are considered to be water sources in Japan (Sawano et al., 2005).

Forest evapotranspiration and therefore runoff can vary with forest properties such as leaf shape (broadleaf/conifer), stem density, and canopy height (e.g., Swank and Douglass, 1974; Vertessy et al., 2001; Komatsu et al., 2008). Thus, some researchers in Japan have suggested that forest management, such as thinning coniferous plantation forests and converting them to broadleaf forests, is a possible way to increase water resources (e.g., Tsukamoto, 1998; Kuraji, 2003). (Here, note that coniferous

\footnotetext{
* Corresponding author. Tel.: +8192948 3109; fax: +81 929483119 .

E-mail address: komatsu@forest.kyushu-u.ac.jp (H. Komatsu).
}

plantation forests are believed to have greater evapotranspiration rates than broadleaf forests in Japan, since the work by Swank and Douglass (1974) in the US has been widely introduced in Japan.)

To evaluate the validity of these suggestions, it is necessary to examine relationships between forest properties and evapotranspiration. In such an examination, researchers often summarize and compare evapotranspiration data from various experimental sites (e.g., Kelliher et al., 1995; Komatsu, 2003a,b, 2005; Komatsu and Hotta, 2007). For examining differences in evapotranspiration induced by forest properties, the effect of variations in meteorological conditions between sites on evapotranspiration should be eliminated (Komatsu and Hotta, 2005; Komatsu, 2007).

When examining differences in dry-canopy evaporation (or transpiration) induced by forest properties, the Priestley-Taylor coefficient in the growing season without soil water deficit and reference surface (or canopy) conductance have been used (e.g., Kelliher et al., 1993; Oren et al., 1999; Komatsu, 2003a,b, 2005; Komatsu et al., 2007b). These parameters exclude the effect of variations in meteorological conditions between sites.

When examining differences in rainfall interception induced by forest properties, the canopy storage parameter (e.g., Shuttleworth, 1989; Hormann et al., 1997) and the annual rainfall interception ratio defined as the annual interception divided by 
annual rainfall (e.g., Hattori, 1992; Ward and Robinson, 2000; Huber and Iroume, 2001; Komatsu et al., 2007a,c) have been used. The canopy storage parameter does not include the effect of variations in meteorological conditions between sites (e.g., Rutter et al., 1971; Gash, 1979), while the annual rainfall interception ratio includes it (e.g., Loustau et al., 1992; Ward and Robinson, 2000; Toba and Ohta, 2005). Thus, the use of the canopy storage parameter is, in principle, more suited than the use of the annual interception ratio for examining differences in rainfall interception induced by forest properties.

However, the use of the canopy storage parameter has a practical limitation, which contrasts to the use of the annual interception ratio. The number of studies reporting canopy storage parameter values is much smaller than that reporting interception ratio values; Komatsu et al. (2007a) summarized annual rainfall interception ratio data for 16 sites in Japan from earlier literature and canopy storage parameter data for only 7 sites were present among the 16 . One possible reason for this would be that determining the canopy storage parameter from observed data is much more difficult than determining the rainfall interception ratio (e.g., Klaassen et al., 1998). Therefore, examinations of differences in rainfall interception induced by forest properties are often based on a comparison of the rainfall interception ratios rather than a comparison of the canopy storage parameters (e.g., Hattori, 1992; Ward and Robinson, 2000; Huber and Iroume, 2001; Komatsu et al., 2007a,c). For example, Komatsu et al. (2007a) summarized rainfall interception ratios observed in Japan from earlier publications and reported two results: (i) there is no clear difference in the interception ratio between broadleaf and coniferous forests and (ii) there is a positive correlation in stem density and the interception ratio for coniferous forests.

This study examines the variation in the annual interception ratio relating to annual rainfall, which would be the primary factor relating to the interception ratio, across Japan with the use of a rainfall interception model assuming the same forest properties (i.e., the canopy storage capacity, canopy closure, leaf area index (LAI), and the bulk coefficient for sensible heat transfer). Based on this examination, a method is then proposed for examining differences in rainfall interception induced by forest properties based on a comparison of the annual rainfall interception ratios from various sites in Japan. This study excludes solitary islands, because rainfall regime on solitary islands is much different from those on the mainland. Heavy snowfall regions in Japan are also excluded because snowfall interception processes are different from those of rainfall interception (Nakai et al., 1999; Lundberg and Halldin, 2001; Yamazaki et al., 2007). Though the regions with heavy snowfall occupy a significant portion of Japan's land surface, the regions do not frequently suffer from water shortage (Komatsu et al., 2007a). Therefore, this limitation of our study is not so critical.

\section{Materials and methods}

\subsection{Model}

A rainfall interception model developed by Kondo et al. (1992a) was used for two reasons. First, Kondo et al.'s (1992a) model has been more frequently applied to forests in Japan than other models (e.g., Rutter et al., 1971, 1975; Gash, 1979) and therefore its applicability for the Japanese climate has been well confirmed (Kondo et al., 1992b,c,d). Kondo et al. (1992b) compared annual interception amounts calculated by the model with those observed in earlier studies and obtained good agreement between them. Furthermore, Kondo and Ishii (1992) reported that seasonal changes in interception amounts were well simulated by the model. Kondo et al. (1992a,c) developed an evapotranspiration model incorporating the interception model as a submodel. They compared annual and monthly evapotranspiration rates calculated by the model and observed by catchment water balance measurements and obtained good agreement between them.

Second, this model only requires daily meteorological data that are available from the Japan Meteorological Agency (http:// www.jma.go.jp/jma/indexe.html), which gives rainfall, solar radiation, temperature, humidity, and wind speed data measured at meteorological stations across Japan.

Kondo et al.'s (1992a) model assumes all rain on a particular day falls in a single storm. For storms smaller than a threshold value, i.e., the amount of rain needed to saturate the canopy, the daily rainfall interception $I_{\mathrm{d}}\left(\mathrm{mm}\right.$ day $\left.^{-1}\right)$ is given by

$I_{\mathrm{d}}=\Omega^{*} P_{\mathrm{d}}$,

where $\Omega^{*}$ is the possibility that raindrops strike the forest canopy and $P_{\mathrm{d}}$ is the daily rainfall $\left(\mathrm{mm} \mathrm{day}^{-1}\right)$. For storms larger than the threshold, $I_{\mathrm{d}}$ is the sum of evaporation during and just after the storm:

$I_{\mathrm{d}}=I_{\mathrm{pot}} \tau_{\mathrm{p}} / 24+S$,

where $I_{\text {pot }}$ is the potential evaporation rate $\left(\mathrm{mm} \mathrm{day}^{-1}\right), \tau_{\mathrm{p}}$ is the rainfall duration (h), and $S$ is the canopy storage of intercepted water $(\mathrm{mm})$.

The threshold value $P_{\mathrm{dt}}$ is given by

$P_{\mathrm{dt}}=\frac{I_{\mathrm{pot}} \tau_{\mathrm{p}} / 24+S_{\max }}{\Omega^{*}}$,

where $S_{\max }$ is the canopy storage capacity ( $\left.\mathrm{mm}\right)$.

$\Omega^{*}, I_{\mathrm{pot}}, \tau_{\mathrm{p}}$, and $S$ need further formulation. $\Omega^{*}$ is given by

$\Omega^{*}=\Omega\left\{1-\exp \left(\frac{-F L}{\Omega}\right)\right\}$

where $\Omega$ is the canopy closure, $F$ is the leaf inclination parameter, and $L$ is the leaf area index (LAI). This equation indicates that $\Omega^{*}$ approaches $\Omega$ with increasing LAI. $\Omega$ is 0.0 for fully open canopies and 1.0 for fully closed canopies. $F$ is 0.0 for vertical leaves, 0.5 for randomly inclined leaves, and 1.0 for horizontal leaves (Kondo and Watanabe, 1992).

$I_{\text {pot }}$ is calculated using the single-layer heat budget model developed by Kondo and Watanabe (1992) with the input of daily meteorological data assuming an evaporative efficiency of 1.0. In this calculation, determination of the bulk coefficient for sensible heat transfer $\left(C_{\mathrm{H}}\right)$ is required.

$\tau_{\mathrm{p}}$ is expressed as

$\tau_{\mathrm{p}}=18\left\{1-\exp \left(\frac{-P_{\mathrm{d}}}{12}\right)\right\}$.

This equation was statistically determined by Kondo et al. (1992a) based on rainfall data obtained from meteorological stations across Japan. The equation indicates a longer rainfall duration for greater daily rainfall. Thus, the model includes information of rainfall duration, though the model works with daily rainfall data.

$S$ is modeled as

$S=S_{\max }\left\{1-\exp \left(\frac{-P_{\mathrm{d}}}{S_{\max }}\right)\right\}$

This equation indicates $S$ approaches $S_{\max }$ as daily rainfall increases. 


\subsection{Analysis}

Kondo et al. (1992c,d) calculated the average annual rainfall interception during 1986-1990 at 66 meteorological stations of the Japan Meteorological Agency across Japan using this model. Their results are shown in Table 1 of Kondo et al. (1992c) and Table 2 of Kondo et al. (1992d). Excluding the results from solitary islands and heavy snowfall regions, we used the results from the 24 stations indicated in Fig. 1. Based on the results and annual rainfall data of the 24 stations for 1986-1990 obtained from the Japan Meteorological Agency (http://www.jma.go.jp/jma/indexe.html), we calculated the rainfall interception ratio of the 24 stations averaged for $1986-1990$.

Kondo et al.'s (1992c,d) model calculations used two parameter sets: a set assuming typical coniferous forests and a set assuming typical broadleaf forests in Japan. For both parameter sets, $\Omega$ and $F$ were given similarly: $\Omega=0.9$ and $F=0.5$. The $\Omega$ value was typical for both coniferous and broadleaf forests in Japan (e.g., Kondo and Ishii, 1992; Murai, 1993). $F$ was set as 0.5, which was also assumed in many other studies (e.g., Kondo and Watanabe, 1992; Watanabe and Mizutani, 1996).

In the coniferous parameter set, $L$ was assumed as $L=6.0$, which was an intermediate value among those reported in earlier studies on coniferous forests in Japan (e.g., Yamanoi and Ohtani, 1992; Tanaka et al., 1996; Murakami, 2002). $C_{H}$ was assumed as 0.008 based on $L=6.0$ and a canopy height of $15 \mathrm{~m}$, which was typical for Japanese coniferous forests, using the relationship between $L$ and $C_{H}$ formulated by Kondo and Watanabe (1992). $S_{\max }$ was assumed as $S_{\max }=2.0$. This value was in the range of $S_{\max }$ values for Japanese coniferous forests summarized by Murai (1993), i.e., $0.66-2.9 \mathrm{~mm}(n=9)$.

In the broadleaf parameter set, $L$ was assumed as

$L=4.5+1.5 \cos \left\{\frac{2 \pi}{12}(M-8)\right\}$,

where $M$ is the month of the year. $L$ has a maximum in August $(L=6.0)$ and a minimum in February $(L=3.0)$ in this equation.
These $L$ values are nearly identical to those reported by Park et al. (2000) and Goto et al. (2005, 2006) for broadleaf forests in Japan. (Note: evergreen and deciduous trees coexist in many Japanese broadleaf forests except heavy snowfall regions and therefore $L$ in winter was assumed to be non-zero). $C_{\mathrm{H}}$ was assumed as 0.010 based on the mean $L$ value throughout the year (4.5) and a canopy height of $15 \mathrm{~m}$, also typical for Japanese broadleaf forests, using the relationship between $L$ and $C_{H}$ formulated by Kondo and Watanabe (1992). $S_{\max }$ was assumed as

$S_{\max }=1.75+0.25 \cos \left\{\frac{2 \pi}{12}(M-8)\right\}$.

$S_{\max }$ has a maximum in August $\left(S_{\max }=2.0\right)$ and a minimum in February $\left(S_{\max }=1.5\right)$ in this equation. The mean $S_{\max }$ throughout the year was 1.75. This value was in the range of $S_{\max }$ values for Japanese broadleaf forests summarized by Murai (1993), i.e., 0.44$3.3 \mathrm{~mm}(n=6)$. The model assumed $S_{\max }$ in February was $75 \%$ of that in August, which was nearly the same value reported by Park et al. (2000) for Shirasaka, Japan. They reported $S_{\max }$ in winter was $76 \%$ of that in summer.

\section{Results}

Table 1 shows annual rainfall, interception, and the interception ratio for the 24 stations. Annual rainfall ranged between 934 and $2674 \mathrm{~mm}$. Stations with low annual rainfall were situated far from the Pacific Ocean (e.g., stations \#2, 5, and 22), while stations with high annual rainfall were situated along the Pacific Ocean (e.g., stations \#12, 20, 23, and 24). Despite the difference in annual rainfall, rainfall amounts were greater during summer than during winter for all of the 24 stations (Fig. 2).

The interception ratio ranged between 0.12 and 0.24 for both parameter sets. Fig. 3 shows the relationship between interception ratios calculated based on each parameter set. We obtained a tight $\left(R^{2}=0.99\right)$, significant correlation $(p<0.001$, Pearson's correlation coefficient test). This indicates that the difference in parameterization caused only a slight change in calculated

Table 1

The average of annual rainfall number of rainy days with daily rainfall greater than $5.0 \mathrm{~mm}$, interception, and interception ratio during $1986-1990$

\begin{tabular}{|c|c|c|c|c|c|c|c|}
\hline \multirow[t]{2}{*}{ No. } & \multirow[t]{2}{*}{ Station name } & \multirow[t]{2}{*}{ Annual rainfall (mm) } & \multirow[t]{2}{*}{ Number of rainy days } & \multicolumn{2}{|l|}{ Coniferous } & \multicolumn{2}{|l|}{ Broadleaf } \\
\hline & & & & Interception (mm) & Interception ratio & Interception (mm) & Interception ratio \\
\hline 1 & Utsunomiya & 1590 & 69.6 & 305 & 0.19 & 302 & 0.19 \\
\hline 2 & Matsumoto & 934 & 51.4 & 226 & 0.24 & 228 & 0.24 \\
\hline 3 & Maebashi & 1331 & 61.8 & 277 & 0.21 & 273 & 0.21 \\
\hline 4 & Nagoya & 1544 & 66.4 & 291 & 0.19 & 288 & 0.19 \\
\hline 5 & Kofu & 1041 & 53 & 249 & 0.24 & 248 & 0.24 \\
\hline 6 & Tokyo & 1503 & 67.2 & 307 & 0.20 & 301 & 0.20 \\
\hline 7 & Omaezaki & 2109 & 76.6 & 318 & 0.15 & 315 & 0.15 \\
\hline 8 & Shizuoka & 2364 & 77.6 & 344 & 0.15 & 335 & 0.14 \\
\hline 9 & Shimonoseki & 1630 & 69.6 & 291 & 0.18 & 295 & 0.18 \\
\hline 10 & Hiroshima & 1618 & 63.6 & 263 & 0.16 & 266 & 0.16 \\
\hline 11 & Osaka & 1381 & 63.4 & 294 & 0.21 & 289 & 0.21 \\
\hline 12 & Shionomisaki & 2537 & 82.8 & 316 & 0.12 & 318 & 0.13 \\
\hline 13 & Nara & 1352 & 67.4 & 257 & 0.19 & 265 & 0.20 \\
\hline 14 & Fukuoka & 1520 & 71 & 305 & 0.20 & 310 & 0.20 \\
\hline 15 & Saga & 1978 & 68.8 & 281 & 0.14 & 285 & 0.14 \\
\hline 16 & Oita & 1687 & 63.4 & 253 & 0.15 & 259 & 0.15 \\
\hline 17 & Nagasaki & 1933 & 70 & 288 & 0.15 & 293 & 0.15 \\
\hline 18 & Kumamoto & 2163 & 80.2 & 316 & 0.15 & 318 & 0.15 \\
\hline 19 & Kagoshima & 2255 & 80.6 & 340 & 0.15 & 340 & 0.15 \\
\hline 20 & Miyazaki & 2527 & 77.6 & 316 & 0.13 & 317 & 0.13 \\
\hline 21 & Matsuyama & 1380 & 70 & 273 & 0.20 & 275 & 0.20 \\
\hline 22 & Takamatsu & 1236 & 58.6 & 245 & 0.20 & 252 & 0.20 \\
\hline 23 & Kochi & 2674 & 77.4 & 317 & 0.12 & 314 & 0.12 \\
\hline 24 & Shimizu & 2596 & 83.4 & 331 & 0.13 & 331 & 0.13 \\
\hline
\end{tabular}


Table 2

Interception ratio observed on Japanese forests (after Komatsu et al., 2007a)

\begin{tabular}{|c|c|c|c|c|c|c|c|c|}
\hline Species & $\begin{array}{l}\text { Stem density } \\
\left(\text { stems ha }{ }^{-1}\right)\end{array}$ & $\begin{array}{l}\text { Canopy } \\
\text { height (m) }\end{array}$ & $\begin{array}{l}\text { Mean } \\
\text { DBH }(\mathrm{cm})\end{array}$ & $\begin{array}{l}\text { Projected } \\
\text { LAI }\end{array}$ & $\begin{array}{l}\text { Measurement } \\
\text { duration (month) }\end{array}$ & $\begin{array}{l}\text { Precipitation } \\
\left(\mathrm{mm} \mathrm{y}^{-1}\right)\end{array}$ & $\begin{array}{l}\text { Interception } \\
\text { ratio }\end{array}$ & References \\
\hline \multicolumn{9}{|l|}{ Broad-leaved } \\
\hline Ilex peduncubsa & 6000 & 7 & & & 12 & 1793 & 0.20 & Iwatsubo and Tsutsumi (1967) \\
\hline Lithocarpus edulis & 3418 & 10.2 & 10.8 & & 12 & 1584 & 0.18 & Sato et al. (2003a,b) \\
\hline Quercus serrata, etc. & 3502 & 6 & 6.9 & $4.4^{\mathrm{a}}$ & 24 & 1478 & 0.13 & Park et al. (2000) \\
\hline Quercus serrata, etc. & 5070 & 20 & 7.1 & $6.4^{\mathrm{a}}$ & 36 & 1396 & 0.24 & Park et al. (2000) \\
\hline \multicolumn{9}{|l|}{ Coniferous } \\
\hline Chamaecyparis obtusa & 3200 & 8 & 7.6 & & 12 & 1793 & 0.26 & Iwatsubo and Tsutsumi (1967) \\
\hline C. obtusa & 2051 & 11 & 16.1 & & 12 & 1543 & 0.21 & Hattori et al. (1982) \\
\hline C. obtusa & 1325 & 13.5 & 18.2 & & 12 & 1087 & 0.19 & Hattori and Chikaarashi (1988) \\
\hline C. obtusa & 1750 & 13.5 & 18.2 & 5.7 & 12 & 1336 & 0.23 & Hattori and Chikaarashi (1988) \\
\hline C. obtusa & 923 & 19.3 & 34.2 & & 30 & 2053 & 0.14 & Tanaka et al. (2005) \\
\hline Cryptomeria japonica & 1467 & 15.2 & 23.2 & & 12 & 1584 & 0.26 & Sato et al. (2003a,b) \\
\hline C. japonica & 750 & 25 & 29 & & 12 & 1150 & 0.12 & Haibara and Aiba (1982) \\
\hline C. japonica & 513 & 26.5 & 38.5 & & 41 & 2304 & 0.16 & Tanaka et al. (2005) \\
\hline C. japonica/C. obtusa & 783 & 18 & 32 & 3.7 & 24 & 1734 & 0.13 & Murakami et al. (2000) \\
\hline Pinus densifbra & 1575 & 7 & 12 & & 12 & 1513 & 0.14 & Mitsudera et al. (1984) \\
\hline P. densifbra & 2300 & 12 & 20 & & 12 & 1291 & 0.21 & Taniguchi et al. (1996) \\
\hline P. densifbra & 1700 & 12 & 20 & & 12 & 1291 & 0.30 & Taniguchi et al. (1996) \\
\hline
\end{tabular}

a LAI values in summer.

interception ratios, which was already pointed out by Kondo et al. (1992b), for the following reasons. First, interception amounts were insensitive to the difference in $C_{\mathrm{H}}$ between the parameter sets. The differences in the monthly interception amounts in August between the parameter sets were caused by the differences in $C_{\mathrm{H}}$, because $L$ (and therefore $S_{\max }$ ) values were the same for both parameter sets in August. However, the differences in the monthly interception in August between the
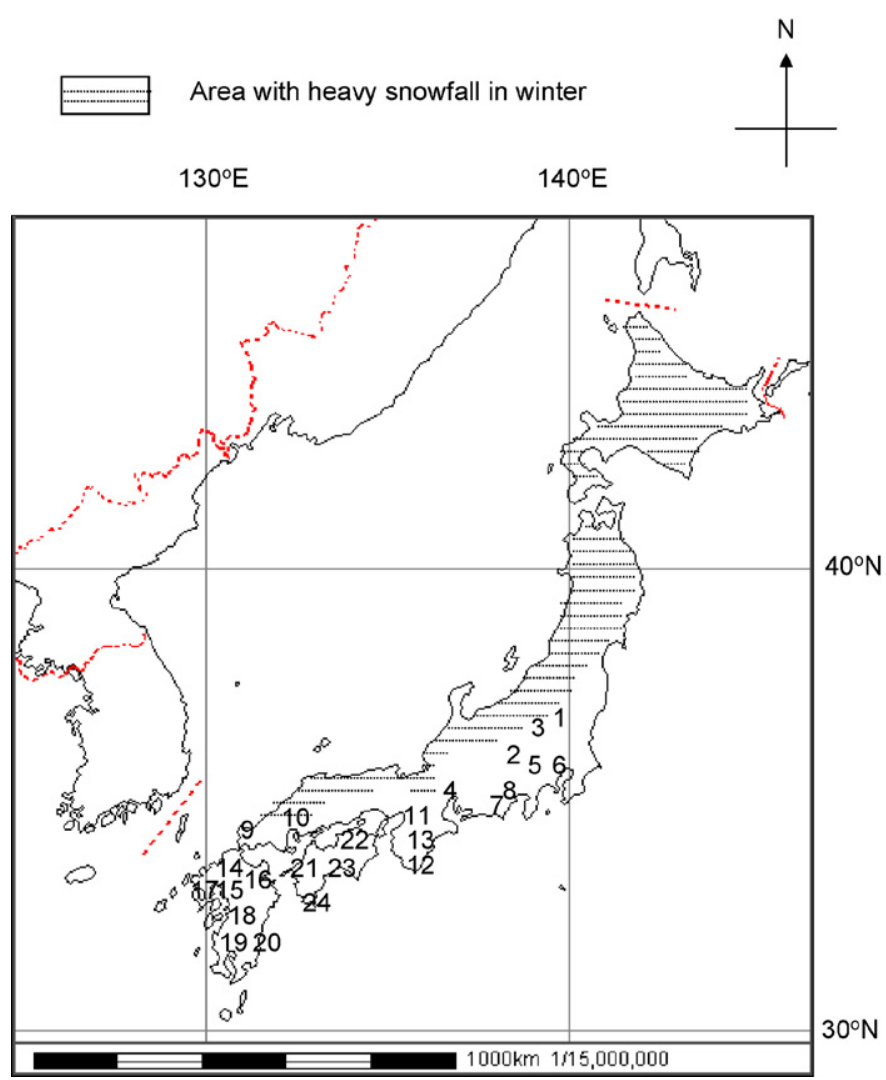

Fig. 1. Locations of the 24 meteorological stations from which data were used in this study. Areas with heavy snowfall in winter are also indicated. Numerals in the figure correspond to station numbers listed in Table 1. parameter sets were typically $\sim 2 \mathrm{~mm}$ (Table 1 of Kondo et al., 1992c; Table 2 of Kondo et al., 1992d), indicating the insensitivity of interception amounts to $C_{\mathrm{H}}$. On the other hand, interception amounts were relatively sensitive to $L$. The difference in $L$ between the parameter sets was more significant in winter than in summer. However, rainfall amounts were small during winter (Fig. 2), resulting in small absolute differences in interception amounts between the parameter sets.

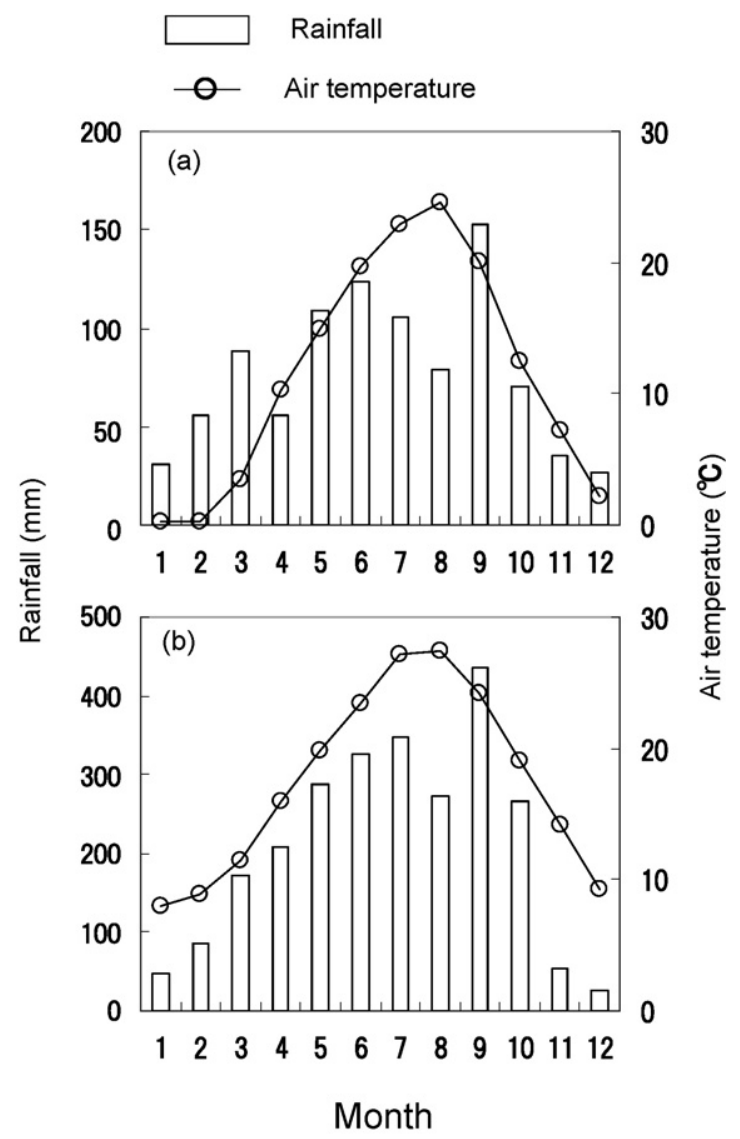

Fig. 2. Seasonality of rainfall and air temperature at two stations with different annual rainfall amounts: (a) Matsumoto (\#2) and (b) Miyazaki (\#20) stations. 


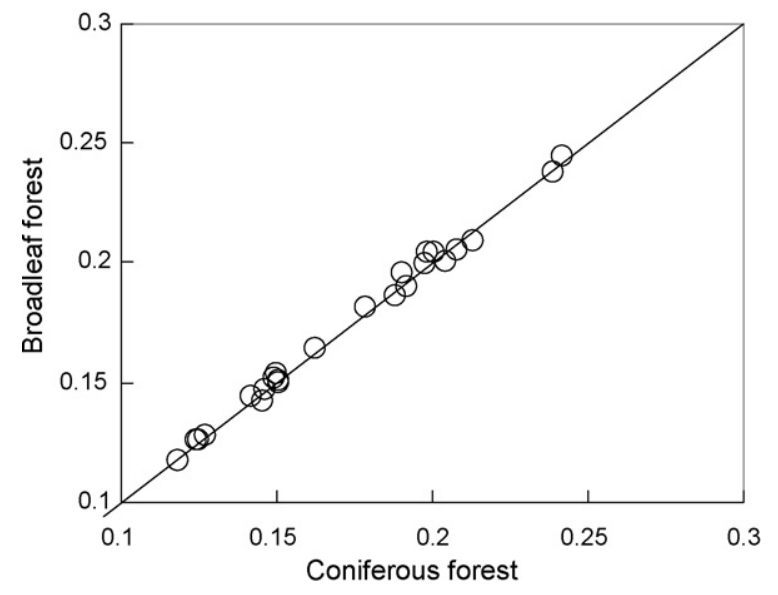

Fig. 3. Relationship between interception ratios calculated using coniferous and broadleaf forest parameter sets. The 1:1 line is also drawn.

Fig. 4a and b shows the relationship between annual rainfall and the interception ratio for each parameter set. A clear $\left(R^{2}=0.91\right.$ and $R^{2}=0.89$ for the coniferous and broadleaf parameter sets, respectively) negative correlation was obtained between them $(p<0.001$ for both parameter sets, Pearson's correlation coefficient test). There are two reasons for the lower interception ratio for greater annual rainfall. First, daily rainfall $P_{\mathrm{d}}$ tends to be greater

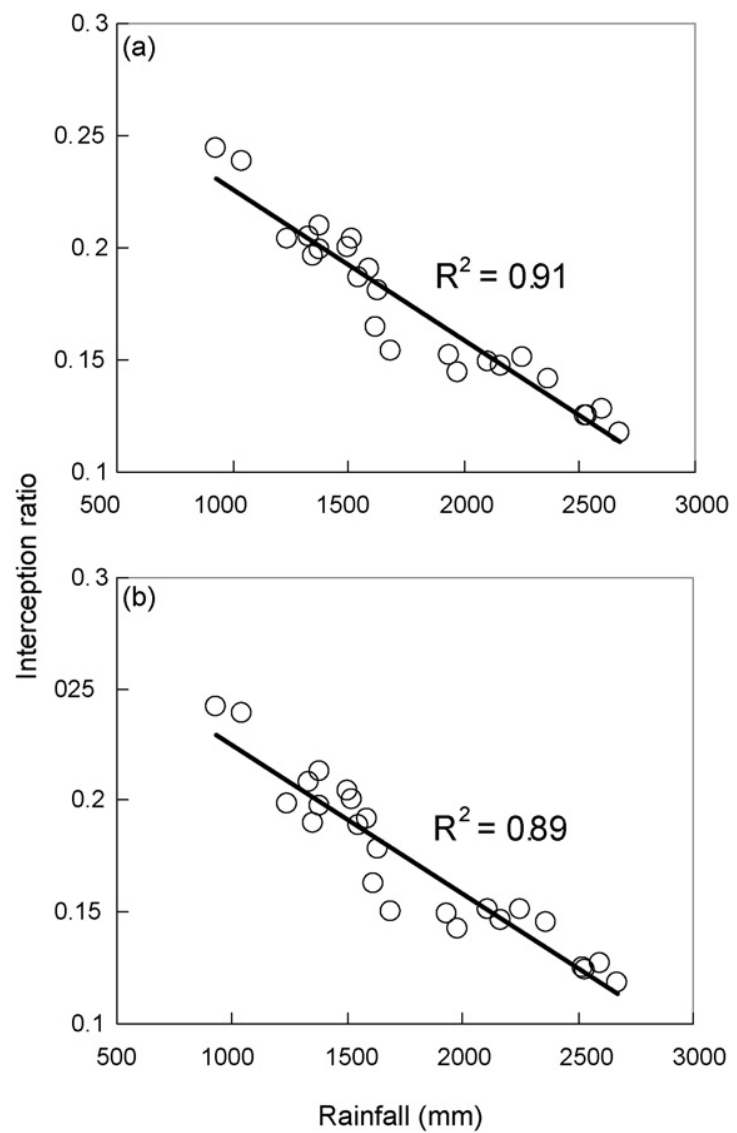

Fig. 4. Relationship between annual rainfall and the interception ratio for the 24 stations based on 5-year average data (1986-1990) calculated using (a) coniferous and (b) broadleaf forest parameter sets. Regression lines in (a) and (b) were determined by the least-squares method as $y=-0.000677 x+0.294$ and $y=-0.0000667 x+0.292$, respectively. where annual rainfall amounts are greater. Second, daily interception $I_{\mathrm{d}}$ is nearly independent of $P_{\mathrm{d}}$ when $P_{\mathrm{d}}$ is greater than the threshold value $P_{\mathrm{dt}}$ though $I_{\mathrm{d}}$ increases with increasing $P_{\mathrm{d}}$ when $P_{\mathrm{d}}$ is lower than $P_{\mathrm{dt}}$ (see Eqs. (1) and (2)).

The high $R^{2}$ value in Fig. 4 was due to the following reasons. According to Kondo et al. (1992c,d), interception amounts are primarily determined by the number of rainy days with $P_{\mathrm{d}} \geq 5.0$ $\mathrm{mm}$ day $^{-1}$ rather than annual rainfall amounts, because (i) the major portion of annual interception amounts is occupied by interception of rainfall greater than $P_{\mathrm{dt}}$, (ii) daily interception is nearly constant when rainfall is greater than $P_{\mathrm{dt}}$, and (iii) $P_{\mathrm{dt}}$ is typically $\sim 5 \mathrm{~mm} \mathrm{day}^{-1}$. These three facts suggest a linear relationship between annual interception and the number of rainy days with $P_{\mathrm{d}} \geq 5.0 \mathrm{~mm}$ day $^{-1}$. Our data also shows a linear relationship between the annual interception amount and the number of rainy days with $P_{\mathrm{d}} \geq 5.0 \mathrm{~mm}$ day $^{-1}$ for both parameter sets (Fig. 5a and b), which agrees with Kondo et al.'s (1992c,d) explanation. On the other hand, the number of rainy days with $P_{\mathrm{d}} \geq 5.0 \mathrm{~mm}$ day $^{-1}$ was significantly $(p<0.001$, Spearman's correlation coefficient test) related to annual rainfall (Fig. 6a), resulting in tight correlation between annual rainfall and interception amounts and therefore between annual rainfall and the interception ratio (Fig. 4). Here, note that the relationship between annual rainfall and the number of rainy days with $P_{\mathrm{d}} \geq 5.0 \mathrm{~mm}$ day $^{-1}$ was nonlinear, because extremely high daily rainfall (mainly associated with typhoons) was recorded in regions with high annual rainfall.

The range in the interception ratio (Table 1 ) indicates that the interception ratio shows regional variations even for the same

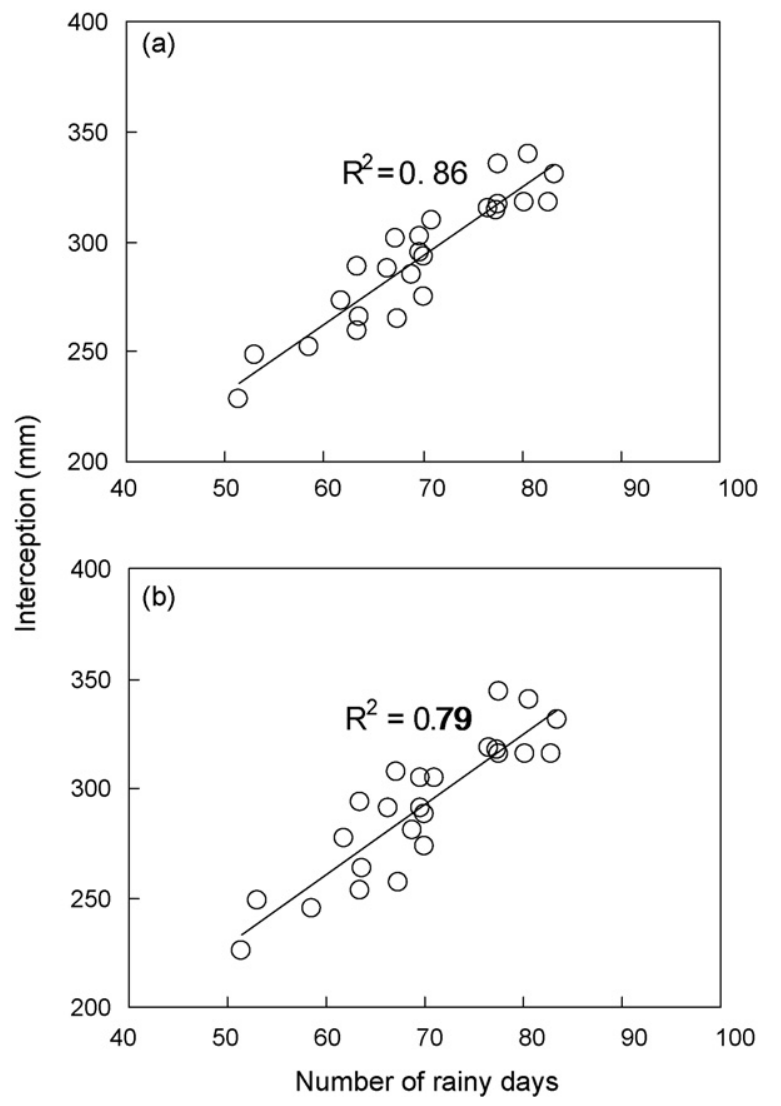

Fig. 5. Relationships between the number of rainy days with $P_{\mathrm{d}} \geq 5.0\left(\mathrm{~mm} \mathrm{day}^{-1}\right)$ and the annual interception calculated using (a) coniferous and (b) broadleaf forest parameter sets. Regression lines in Fig. $4 \mathrm{a}$ and $\mathrm{b}$ were determined by the leastsquares method as $y=3.12 x+74.9$ and $y=3.20 x+68.9$, respectively. 


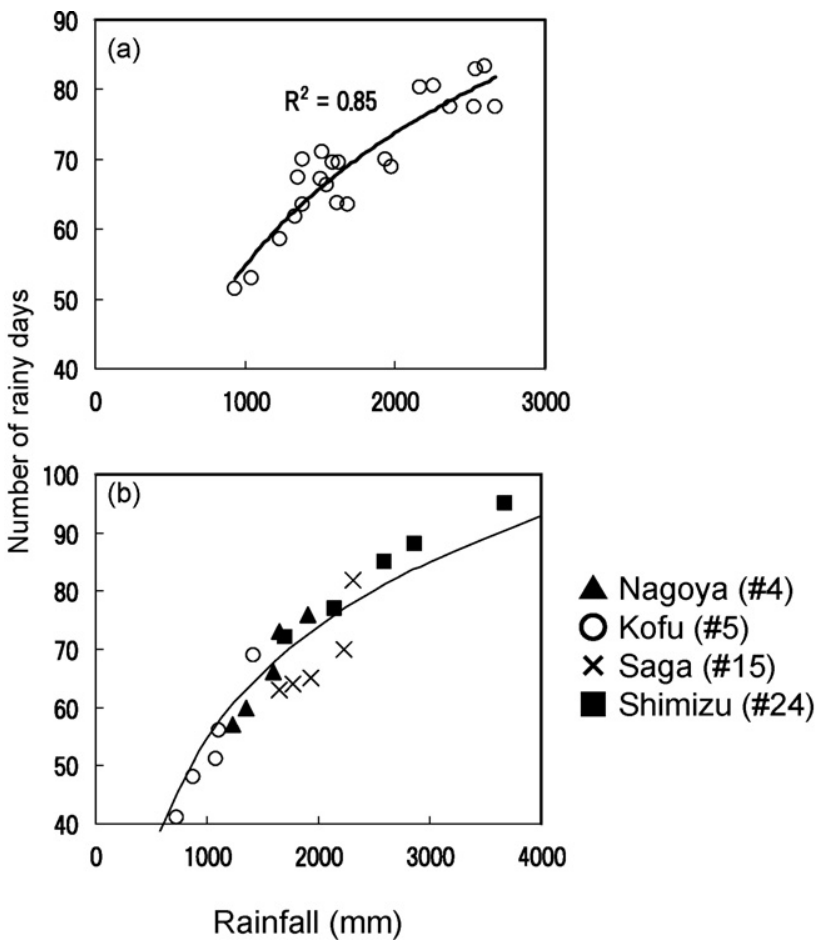

Fig. 6. (a) Relationship between annual rainfall and the number of rainy days with $P_{\mathrm{d}} \geq 5.0\left(\mathrm{~mm} \mathrm{day}^{-1}\right)$ for the 24 stations of the Japan Meteorological Agency based on 5-year average data (1986-1990). (b) Relationship between annual rainfall and the number of rainy days with $P_{\mathrm{d}} \geq 5.0\left(\mathrm{~mm} \mathrm{day}^{-1}\right)$ for each year from 1986 to 1990 . Data from four stations with different annual rainfall amounts are shown in (b). Data from the other stations were not plotted in this figure to avoid complexity. Data from the other stations also show qualitatively the same results as those for the data plotted in (b). The regression line in (a) was determined by the leastsquares method as $y=27.6 \ln x-136$. The line in (b) is the same as that in (a).

forest properties and therefore the difference in rainfall interception induced by forest properties cannot be purely assessed by a comparison of the interception ratios from various sites across Japan. The tight relationship between the annual rainfall amount and the interception ratio (Fig. 4) suggests that considering the variation in annual rainfall is critical for assessing the difference in rainfall interception induced by forest properties.

Our analysis was based on 5-year average (1986-1990) rainfall and interception data. In reality, measurement periods of most rainfall interception studies are less than 5 years (e.g., Park et al., 2000; Sato et al., 2003a,b). However, our results would hold for data of less than 5 years. Fig. $6 \mathrm{~b}$ shows relationships between annual rainfall and the number of rainy days with $\geq 5.0 \mathrm{~mm} \mathrm{day}^{-1}$ for each year from 1986 to 1990 . Data samples were located along the regression line determined by the 5 -year average data. This indicates the relationship between annual rainfall and the number of rainy days with $\geq 5.0 \mathrm{~mm} \mathrm{day}^{-1}$ holds for 1 -year data. Thus, the relationship between annual rainfall and the interception ratio in Fig. 4 should hold for 1-year data.

\section{Discussion}

\subsection{Implications for intercomparison}

As mentioned in the introduction, our previous work (Komatsu et al., 2007a) compared the annual rainfall interception ratios observed at different sites in Japan (Table 2), without considering the variation in annual rainfall amounts between sites, to examine differences in rainfall interception amounts induced by forest properties. It concluded (i) there is no clear difference in
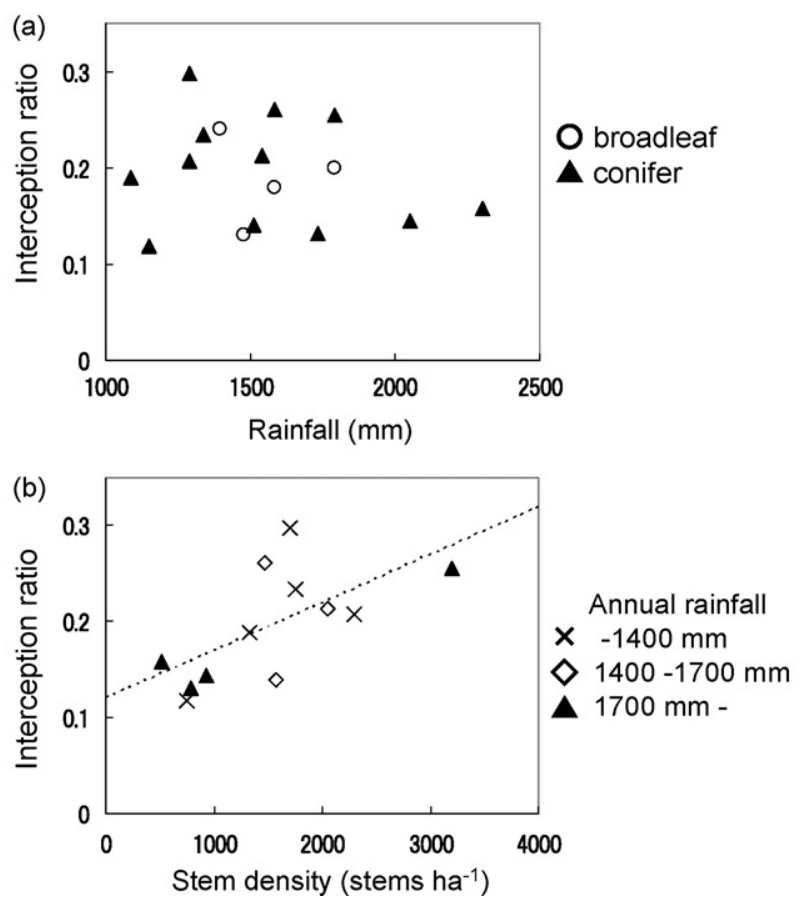

Fig. 7. (a) Relationships between annual rainfall and the interception ratio for broadleaf and coniferous forests. (b) Relationship between stem density and the annual interception ratio for coniferous forests classified by annual rainfall. The line was determined by the least squares method, applied to all data samples, as $y=0.0000498 x+0.12$. Data were obtained from Table 2 .

interception amounts between broadleaf and coniferous forests and (ii) there is a positive correlation ( $p<0.05$, Pearson's correlation coefficient test) in stem density and interception amounts for coniferous forests. The first conclusion is supported by the fact that rainfall amounts are small during winter when the difference in $L$ between broadleaf and coniferous forests are most significant. The second conclusion is supported by the fact that $L$ of coniferous forests negatively correlates with stem density for coniferous forests except for the very young stage ( $<$ ca. 15 years old) (Murakami, 2002), indicating greater $S_{\max }$ for coniferous forests with higher stem density. The following examines whether these two conclusions still hold when considering the variation in the annual rainfall amount between sites.

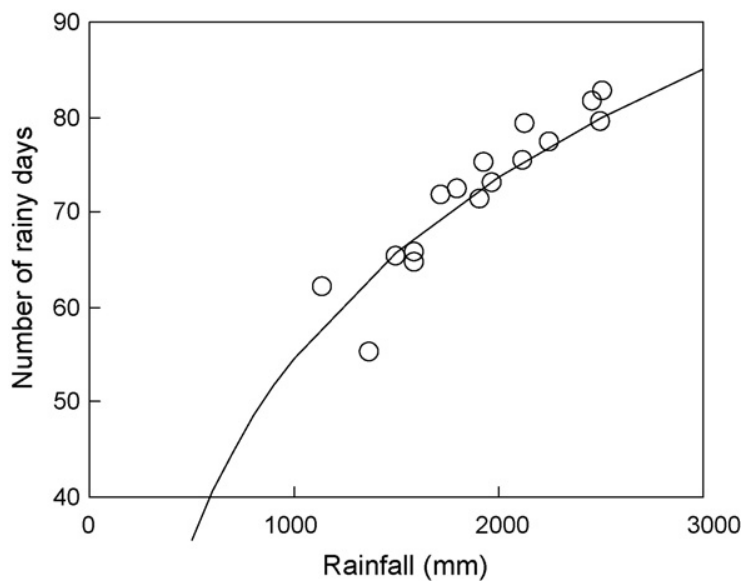

Fig. 8. Relationship between annual rainfall and the number of rainy days with $P_{\mathrm{d}} \geq 5.0\left(\mathrm{~mm} \mathrm{day}^{-1}\right)$ for data from observation sites located in forested regions (Table 3). The line is the same as that in Fig. 6a. 
Table 3

The average of annual rainfall and number of rainy days with daily rainfall greater than $5.0 \mathrm{~mm}$ for observation sites in forested area

\begin{tabular}{|c|c|c|c|c|c|c|}
\hline Station name & Latitude, longitude & $\begin{array}{l}\text { Altitude } \\
(\mathrm{m})\end{array}$ & $\begin{array}{l}\text { Observation } \\
\text { period of the } \\
\text { data }\end{array}$ & $\begin{array}{l}\text { Annual } \\
\text { rainfall } \\
(\mathrm{mm})\end{array}$ & $\begin{array}{l}\text { Number of } \\
\text { rainy days }\end{array}$ & References \\
\hline Shinta & $35^{\circ} 12^{\prime} \mathrm{N}, 140^{\circ} 06^{\prime} \mathrm{E}$ & 236 & 1995-2000 & 2118 & 75.5 & Komatsu et al. (2006a,b) \\
\hline Kiyosumi & $35^{\circ} 09^{\prime} \mathrm{N}, 140^{\circ} 09^{\prime} \mathrm{E}$ & 300 & 2002-2005 & 2253 & 77.3 & $\begin{array}{l}\text { The University Forests Graduate School of Agricultural and } \\
\text { Life Sciences The University of Tokyo }(2003,2004,2005,2006,2007)\end{array}$ \\
\hline Amatsu & $35^{\circ} 07^{\prime} \mathrm{N}, 140^{\circ} 09^{\prime} \mathrm{E}$ & 15 & 2001-2005 & 1973 & 73 & $\begin{array}{l}\text { The University Forests Graduate School of Agricultural and } \\
\text { Life Sciences The University of Tokyo }(2003,2004,2005,2006,2007)\end{array}$ \\
\hline Fudago & $35^{\circ} 12^{\prime} \mathrm{N}, 140^{\circ} 09^{\prime} \mathrm{E}$ & 206 & 2001-2005 & 2513 & 82.6 & $\begin{array}{l}\text { The University Forests Graduate School of Agricultural and } \\
\text { Life Sciences The University of Tokyo }(2003,2004,2005,2006,2007)\end{array}$ \\
\hline Godai & $35^{\circ} 12^{\prime} \mathrm{N}, 140^{\circ} 09^{\prime} \mathrm{E}$ & 221 & 2001-2005 & 2460 & 81.6 & $\begin{array}{l}\text { The University Forests Graduate School of Agricultural and } \\
\text { Life Sciences The University of Tokyo }(2003,2004,2005,2006,2007)\end{array}$ \\
\hline Tanashi & $35^{\circ} 44^{\prime} \mathrm{N}, 139^{\circ} 32^{\prime} \mathrm{E}$ & 60 & 2001-2005 & 1587 & 65.8 & $\begin{array}{l}\text { The University Forests Graduate School of Agricultural and } \\
\text { Life Sciences The University of Tokyo }(2003,2004,2005,2006,2007)\end{array}$ \\
\hline Tochimoto & $35^{\circ} 56^{\prime} \mathrm{N}, 138^{\circ} 52^{\prime} \mathrm{E}$ & 740 & 2003-2005 & 1500 & 65.3 & $\begin{array}{l}\text { The University Forests Graduate School of Agricultural and } \\
\text { Life Sciences The University of Tokyo }(2003,2004,2005,2006,2007)\end{array}$ \\
\hline Oochigawa & $35^{\circ} 55^{\prime} \mathrm{N}, 138^{\circ} 59^{\prime} \mathrm{E}$ & 650 & 2003-2005 & 1593 & 64.7 & $\begin{array}{l}\text { The University Forests Graduate School of Agricultural and } \\
\text { Life Sciences The University of Tokyo }(2003,2004,2005,2006,2007)\end{array}$ \\
\hline Kagemori & $35^{\circ} 59^{\prime} \mathrm{N}, 139^{\circ} 05^{\prime} \mathrm{E}$ & 240 & 2002-2005 & 1373 & 55.3 & $\begin{array}{l}\text { The University Forests Graduate School of Agricultural and } \\
\text { Life Sciences The University of Tokyo }(2003,2004,2005,2006,2007)\end{array}$ \\
\hline Kanou & $34^{\circ} 39^{\prime} \mathrm{N}, 138^{\circ} 51^{\prime} \mathrm{E}$ & 10 & 2001-2005 & 1914 & 71.4 & $\begin{array}{l}\text { The University Forests Graduate School of Agricultural and } \\
\text { Life Sciences The University of Tokyo }(2003,2004,2005,2006,2007)\end{array}$ \\
\hline Aono & $34^{\circ} 41^{\prime} \mathrm{N}, 138^{\circ} 51^{\prime} \mathrm{E}$ & 105 & 2001-2005 & 2130 & 79.2 & $\begin{array}{l}\text { The University Forests Graduate School of Agricultural and } \\
\text { Life Sciences The University of Tokyo }(2003,2004,2005,2006,2007)\end{array}$ \\
\hline Shirasaka & $35^{\circ} 12^{\prime} \mathrm{N}, 137^{\circ} 10^{\prime} \mathrm{E}$ & 304 & 1986-1990 & 1925 & 75.2 & The Tokyo University Forest in Aichi (1999) \\
\hline Ananomiya & $35^{\circ} 15^{\prime} \mathrm{N}, 137^{\circ} 06^{\prime} \mathrm{E}$ & 148 & $2002-2004$ & 1717 & 71.7 & $\begin{array}{l}\text { The University Forests Graduate School of Agricultural and } \\
\text { Life Sciences The University of Tokyo }(2003,2004,2005,2006,2007)\end{array}$ \\
\hline Tatsunokuch: & $34^{\circ} 42^{\prime} \mathrm{N}, 133^{\circ} 58^{\prime} \mathrm{E}$ & 40 & 1996-2000 & 1135 & 62 & Goto et al. (2005) \\
\hline Ochozu & $33^{\circ} 38^{\prime} \mathrm{N}, 130^{\circ} 32^{\prime} \mathrm{E}$ & $170-300$ & 2003-2005 & 1802 & 72.3 & Komatsu et al. (2007c) \\
\hline Sarukawa & $31^{\circ} 51^{\prime} \mathrm{N}, 131^{\circ} 13^{\prime} \mathrm{E}$ & $202-370$ & 1967-1971 & 2495 & 79.4 & Forest Influences Unit Kyushu Branch Station (1982) \\
\hline
\end{tabular}

Fig. 7a shows relationships between annual rainfall and the interception ratio for broadleaf and coniferous forests. No clear difference was observed between the forest types for a similar annual rainfall class. Fig. $7 \mathrm{~b}$ shows the relationship between stem density and the interception ratio for coniferous plantation forests classified by annual rainfall. Data with high interception ratio values are not always obtained under low annual rainfall conditions. Similarly, data with low interception ratio values are not always obtained under high annual rainfall conditions. Thus, the positive correlation between stem density and the interception ratio for coniferous forests cannot be explained by the variation in annual rainfall amounts between sites. Thus, both conclusions of Komatsu et al. (2007a) hold when considering the variation in the annual rainfall amount between sites.

The above discussion is based on the tight relationship between annual rainfall and the interception ratio (Fig. 4). This relationship stems from the relationship between annual rainfall and the number of rainy days with $P_{\mathrm{d}} \geq 5.0 \mathrm{~mm}$ day $^{-1}$ (Fig. 6a). Though most of the 24 meteorological stations, the data of which was used in this study, were located in urban areas, most of the evapotranspiration measurement sites were situated in forested regions with complex terrain far from urban areas. If the relationship between annual rainfall and the number of rainy days with $P_{\mathrm{d}} \geq 5.0 \mathrm{~mm}^{-1 a y}{ }^{-1}$ for forested regions was different from that for urban area, the above discussion would be invalid. Fig. 8 shows the relationship between annual rainfall and the number of rainy days with $P_{\mathrm{d}} \geq 5.0 \mathrm{~mm} \mathrm{day}^{-1}$ for data obtained in forested regions (Table 3 ). The data were summarized from earlier publications applying two criteria: (i) there were no missing data for the succeeding 3 years and (ii) the observation site was located outside regions with heavy snowfall. The data from forested regions are plotted around the regression line determined based on data from the 24 stations. Thus, the relationship between annual rainfall and the number of rainy days with $P_{\mathrm{d}} \geq 5.0 \mathrm{~mm}$ day ${ }^{-1}$ developed from data obtained in urban areas holds for data obtained in forested regions, indicating the validity of the above discussion.

\subsection{Qualification of model calculation results}

As described in Section 2.1, the validity of the model was already confirmed by Kondo and Ishii (1992) and Kondo et al. (1992a,b,c). Thus, the negative correlation between annual rainfall and the interception ratio (Fig. 4) would be reliable. However, qualification of the results based on observation data would be useful for strengthening the reliability.

Fig. 9 shows the relationship between annual rainfall and the observed interception ratio reported in earlier studies. Note that

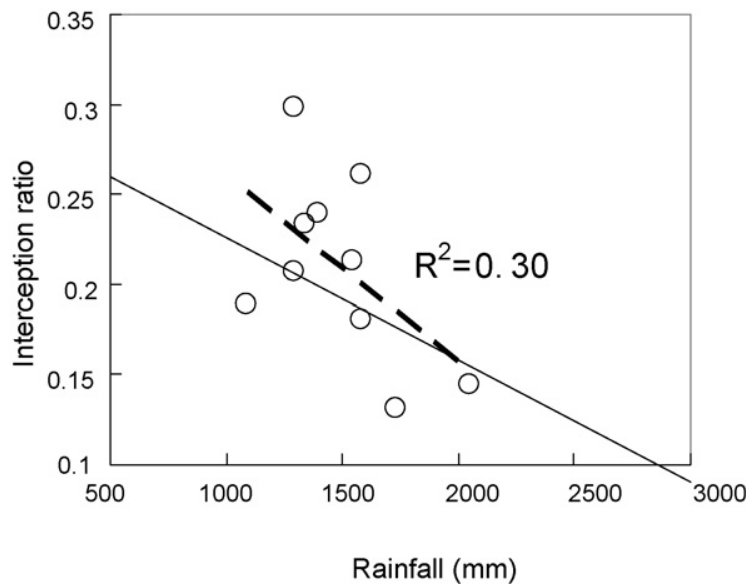

Fig. 9. Relationship between annual rainfall and the interception ratio based on observed data summarized by Table 2. Only data satisfying canopy height of $10-20 \mathrm{~m}$ are plotted. The solid line is the same as that in Fig. 4a. The dotted line indicates the regression line for the observed data, which is determined by the least-squares method as $y=-0.000103 x+0.364$. 
only data observed in forests with a canopy height of 10-20 m are plotted because the model calculations assumed a canopy height of $15 \mathrm{~m}$ and because data observed in forests with a canopy height outside the range would be plotted far from the calculated relationship due to the difference in canopy height. Despite some scattering, the data were plotted around the regression line for the model calculation results. The observed data also show a negative correlation ( $p \leq 0.10$, Pearson's correlation coefficient test), which agrees with the model calculation results. These relationships strengthen the reliability of our model calculation results.

\section{Conclusions}

This study examined the variation in the annual interception ratio relating to annual rainfall across Japan with the use of a rainfall interception model assuming the same forest properties (i.e., the canopy storage capacity, canopy closure, leaf area index (LAI), and the bulk coefficient for sensible heat transfer). The ratio ranged between 0.12 and 0.24 and was highly correlated to annual rainfall. This indicates that considering the difference in annual rainfall is critical for assessing the difference in rainfall interception induced by forest properties. Results from our previous study (Komatsu et al., 2007a) that compared interception ratio data between sites with different forest properties still held when considering differences in annual rainfall between sites.

This study is the first that evaluated the regional variation in the annual rainfall interception ratio across Japan assuming the same forest properties. We believe the results of this study are reliable because the model used in this study (Kondo et al., 1992a) has been tested under Japanese meteorological conditions (Kondo et al., $1992 b, c, d)$. However, it is unclear at this stage whether the results are the same when using other rainfall interception models. Thus, similar studies using other models are recommended to strengthen the robustness of our conclusions. Several studies have pointed out the dependency of interception evaporation rates on rainfall intensity (e.g., Jackson, 2000; Murakami, 2006), though traditional models (e.g., Rutter et al., 1971; Gash, 1979) including the model used in this study do not consider this dependency. Thus, it is highly recommended to examine whether our conclusions hold using rainfall interception models considering the dependency of interception evaporation rates on rainfall intensity (e.g., Murakami, 2007).

\section{Acknowledgements}

We would like to thank Dr. Shinji Sawano (National Institute for Agro-Environmental Sciences, Japan) for fruitful discussion on the relationship between annual rainfall and the interception ratio. Thanks are also due to two anonymous reviewers for their critical and constructive comments. This research has been supported by a Grant-in-Aid for Scientific Research from the Japanese Ministry of Education, Culture, Sports, Science and Technology (\#20780119).

\section{References}

Dairaku, K., Kuraji, K., Suzuki, M., Tangtham, N., Jirasuktaveekul, W., Punyatrong, K., 2000. The effect of rainfall duration and intensity on orographic rainfall enhancement in a mountainous area: a case study in the Mae Chaem watershed, Thailand. J. Jpn. Soc. Hydrol. Water Resour. 13, 57-68.

Dairaku, K., Emori, S., Oki, T., 2004. Rainfall amount, intensity, duration, and frequency relationships in the Mae Chaem Watershed in Southeast Asia. J. Hydrometeor. 5, 458-470.

Forest Influences Unit Kyushu Branch Station, 1982. Statistical report of hydrological observation at Sarukawa experimental watershed (January 1967December 1976). Bull. FFPRI 317, 147-190 (in Japanese).

Gash, J.H.C., 1979. Analytical model of rainfall interception by forests. Quart. J. R. Meteorol. Soc. 105, 43-55.
Goto, Y., Tamai, K., Kominami, Y., Miyama, T., 2005. Hydrological observation reports in Tatsunokuchi-yama experimental forest (January, 1981-December 2000). Bull. FFPRI 394, 87-133 (in Japanese with English summary).

Goto, Y., Tamai, K., Miyama, T., Kominami, Y., Hosoda, I., 2006. Effects of disturbance on vertical stratification of broad-leaved secondary forests in Tatsunokuchiyama experimental forest. Bull. FFPRI 400, 215-225 (in Japanese with English summary).

Haibara, K., Aiba, Y., 1982. The nutrient circulation and budget for a small catchment basin of an established Sugi (Cryptomeria japonica D. Don) and Hinoki (Chamaecyparis obtuse S. et Z.) stand. J. Jpn. Forest. Soc. 64, 8-14 (in Japanese with English summary).

Hattori, S., 1992. Components of forest evapotranspiration. In: Tsukamoto, Y. (Ed.), Forest Hydrology. Bunneido Shuppan, Tokyo (in Japanese).

Hattori, S., Chikaarashi, H., 1988. Effect of thinning on canopy interception in a hinoki stand. Jpn. J. Forest. Soc. 70, 529-533 (in Japanese with English summary).

Hattori, S., Chikaarashi, H., Takeuchi, N., 1982. Measurement of the rainfall interception and its micrometeorological analysis in a Hinoki stand. Bull. FFPRI 318, 79-102 (in Japanese with English summary).

Huber, A., Iroume, A., 2001. Variability of annual rainfall partitioning for different sites and forest covers in Chile. J. Hydrol. 248, 78-92.

Iwatsubo, G., Tsutsumi, T., 1967. On the amount of plant nutrients supplied to the ground by rainwater in adjacent open plot and forests (2). Bull. Kyoto Univ. Forest 39, 110-124 (in Japanese with English summary).

Jackson, N.A., 2000. Measured and modelled rainfall interception loss from an agroforestry system in Kenya. Agric. Forest Meteorol. 100, 323-336.

Kelliher, F.M., Leuning, R., Schulze, E.D., 1993. Evaporation and canopy characteristics of coniferous forests and grasslands. Oecologia 95, 153-163.

Kelliher, F.M., Leuning, R., Raupach, M.R., Schulze, E.D., 1995. Maximum conductances for evaporation from global vegetation types. Agric. Forest Meteorol. 73, $1-16$.

Klaassen, W., Bosveld, F., de Water, E., 1998. Water storage and evaporation as constituents of rainfall interception. J. Hydrol. 212-213, 36-50.

Komatsu, H., 2003a. Values of the decoupling factor observed on forest canopies. J. Jpn. Soc. Hydrol. Water Resour. 16, 427-442 (in Japanese with English summary).

Komatsu, H., 2003b. Relationship between canopy height and the reference value of surface conductance for closed coniferous stands. Hydrol. Process. 17, 2503 2512.

Komatsu, H., 2005. Forest categorization according to dry-canopy evaporation rates in a growing season: comparison of the Priestley-Taylor coefficient values from various observation sites. Hydrol. Process. 19, 3873-3896.

Komatsu, H., 2007. Comparison of forest evapotranspiration from various sites. In: Forest Hydrology Editorial Committee. (Ed.), Forest Hydrology. Morikita Shuppan, Tokyo (in Japanese)

Komatsu, H., Hotta, N., 2005. What has been clarified by numerous forest evapotranspiration studies based on flux measurements? J. Jpn. Soc. Hydrol. Water Resour. 18, 613-626 (in Japanese with English summary).

Komatsu, H., Hotta, N., 2007. Relationship between stem density and dry-canopy evaporation rates in coniferous forests. J. Hydrol. 332, 271-275.

Komatsu, H., Kang, Y., Kume, T., Yoshifuji, N., Hotta, N., 2006a. Transpiration from a Cryptomeria japonica plantation, part 1: aerodynamic control of transpiration. Hydrol. Process. 20, 1309-1320.

Komatsu, H., Kang, Y., Kume, T., Yoshifuji, N., Hotta, N., 2006b. Transpiration from a Cryptomeria japonica plantation, part 2: responses of canopy conductance to meteorological factors. Hydrol. Process. 20, 1321-1334.

Komatsu, H., Tanaka, N., Kume, T., 2007a. Do coniferous forests evaporate more water than broad-leaved forests in Japan? J. Hydrol. 336, 361-375.

Komatsu, H., Hotta, N., Kume, T., 2007b. What is the best way to represent surface conductance for a range of vegetated sites? Hydrol. Process. 21, 1142-1147.

Komatsu, H., Ide, J., Shinohara, Y., Haga, H., Fujiyama, Y., Miyano, T., Maruno, R., Chiwa, M., Kume, T., Higashi, N., Otsuki, K., 2007c. Evapotranspiration of nonmanaged coniferous plantations. Suiri Kagaku 297, 107-127 (in Japanese).

Komatsu, H., Kume, T., Otsuki, K., 2008. The effect of converting a native broadleaved forest to a coniferous plantation forest on annual water yield: a pairedcatchment study in northern Japan. Forest Ecol. Manage. 255, 880-886.

Kondo, J., Ishii, M., 1992. Estimation of rainfall interception loss from forest canopies and comparison with measurements. J. Jpn. Soc. Hydrol. Water Resour. 5 (1) 27-34 (in Japanese with English summary).

Kondo, J., Watanabe, T., 1992. Studies on the bulk transfer-coefficients over a vegetated surface with a multilayer energy budget model. J. Atoms Sci. 49, 2183-2199.

Kondo, J., Nakazono, M., Ishii, M., 1992a. Estimation of forest rainfall interception. Tenki 39, 159-167 (in Japanese).

Kondo, J., Watanabe, T., Nakazono, M., 1992b. Heat budget evaluation of forest evapotranspiration. Tenki 39, 685-695 (in Japanese).

Kondo, J., Nakazono, M., Watanabe, T., 1992c. Hydrological climate in Japan (2): forest rainfall interception. J. Jpn. Soc. Hydrol. Water Resour. 5 (2), 29-36 (in Japanese with English summary)

Kondo, J., Nakazono, M., Watanabe, T., Kuwagata, T., 1992d. Hydrological climate in Japan (3): evapotranspiration from forest. J. Jpn. Soc. Hydrol. Water Resour. 5 (4), 8-18 (in Japanese with English summary).

Kuraji, K., 2003. Effects of forests on stabilizing runoff. Nihon Chisan-Chisui Kyokai, Tokyo (in Japanese). 
Kuraji, K., Punyatrong, K., Suzuki, M., 2001. Altitudinal increase in rainfall in the Mae Chaem watershed. Thai. J. Meteorol. Soc. Jpn. 79, 353-363.

Loustau, D., Berbigier, P., Granier, A., 1992. Interception loss, throughfall and stemflow in a maritime pine stand. II. An application of Gash's analytical model of interception. J. Hydrol. 138, 469-485.

Lundberg, A., Halldin, S., 2001. Snow interception evaporation. Review of measurement techniques, processes, and models. Theor. Appl. Climatol. 70, 117-133.

Mitsudera, M., Kamata, Y., Nakane, K., 1984. Effect of fire on water and major nutrient budgets in forest ecosystems III. Rainfall interception by forest canopy. Jpn. J. Ecol. 34, 15-25.

Murai, H., 1993. Comparison of hydrological characteristics among broad-leaved and coniferous forests and grasslands. Suiri Kagaku 211, 1-40 (in Japanese).

Murakami, 2002. Dependency of LAI and evapotranspiration on stand age at planted stand of Japanese cypress (Chamaecyparis obtuse) and cedar (Cryptomeria japonica) and its potential for the application to the management of water conservation forest. J. Jpn. Soc. Hydrol. Water Resour. 15, 461-471 (in Japanese with English summary)

Murakami, S., 2006. A proposal for a new forest canopy interception mechanism: splash droplet evaporation. J. Hydrol. 319, 72-82.

Murakami, S., 2007. Application of three canopy interception models to a young stand of Japanese cypress and interpretation in terms of interception mechanism. J. Hydrol. 342, 305-319.

Murakami, S., Tsuboyama, Y., Shimizu, T., Fujieda, M., Noguchi, S., 2000. Variation of evapotranspiration with stand age and climate in a small Japanese forested catchment. J. Hydrol. 227, 114-127.

Nakai, Y., Sakamoto, T., Terajima, T., Kitamura, K., Shirai, T., 1999. The effect of canopy-snow on the energy balance above a coniferous forest. Hydrol. Process. 13, 2371-2382.

Oren, R., Sperry, J.S., Pataki, D.E., Ewers, B.E., Phillips, N., Schafer, K.V.R., 1999. Survey and synthesis of intra- and interspecific variation in stomatal sensitivity to vapour pressure deficit. Plant Cell Environ. 22, 1515-1526.

Park, H.T., Hattori, S., Kang, H.M., 2000. Seasonal and inter-plot variations of stemflow, throughfall and interception loss two deciduous broad-leaved forests. J. Jpn. Soc. Hydrol. Resour. 13, 17-30.

Rutter, A.J., Kershaw, K.A., Robins, P.C., Morton, A.J., 1971. A predictive model of rainfall interception in forests. I. Deriviation of the model from observations in a plantation of Corsican pine. Agric. Meteorol. 9, 367-384.

Rutter, A.J., Morton, A.J., Robins, P.C., 1975. A predictive model of rainfall interception in forests. II. Generalization of the model and comparison with observations in some coniferous and hardwood stands. J. Appl. Ecol. 12, 367-381.

Sato, Y., Otsuki, K., Ogawa, S., 2003a. Estimation of annual canopy interception by Lithocarpus edulis Nakai. Bull. Kyushu Univ. Forest 83, 15-29 (in Japanese with English summary).

Sato, Y., Kume, A., Otsuki, K., Ogawa, S., 2003b. Effects of diference in canopy structure on the distribution of thoughfall-a comparison of throughfall cahracteristics between the coniferous forest and the broad-leaved forest. J. Jpn. Soc. Hydrol. Water Resour. 16, 605-616 (in Japanese with English summary).

Sawano, S. Komatsu, H., Suzuki, M. 2005. Differences in annual precipitation amounts between forested area, agricultural area, and urban area in Japan. J. Jpn. Soc. Hydrol. Water Resour. 18, 435-440 (in Japanese with English summary).

Shuttleworth, W.J., 1989. Micrometeorology of temperate and tropical forest. Phil. Trans. R. Soc. Lond. B 324, 299-334.

Swank, W.T., Douglass, J.E., 1974. Streamflow greatly reduced by converting deciduous hardwood stands to pine. Science 185, 857-859.

Tanaka, K., Tanaka, H., Nakamura, A., Ohte, N., Kobashi, S., 1996. Conductance at community level and characteristics of $\mathrm{CO}_{2}$ exchange in hinoki (Chamaecyparis obtuse) stand. J. Jpn. Forest Soc. 78, 266-272 (in Japanese with English summary).

Tanaka, N., Kuraji, K, Shiraki, K., Suzuki, Y., Suzuki, M., Ohta, T., Suzuki, M., 2005 Throughfall, stemflow and rainfall interception at mature Cryptomeria japonica and Chamaecyparis obtusa stands in Fukuroyamasawa watershed. Bull. Tokyo Univ. Forest 113, 197-240 (in Japanese with English summary).

Taniguchi, M., Tsujimura, M., Tanaka, T., 1996. Significance of stemflow in groundwater recharge 1: evaluation of the stemflow contribution to recharge using a mass balance approach. Hydrol. Process. 10, 71-80.

The Tokyo University Forest in Aichi, 1999. Report of the daily runoff in the Tokyo University Forest in Aichi (VI). The Tokyo Univ. Forest 38, 127-146 (in Japanese).

The University Forests Graduate School of Agricultural and Life Sciences The University of Tokyo, 2003. Annual Report of Meteorological Observations in the University Forests. The University of Tokyo (January 2001-December 2001). The University Forests 42, 209-231.

The University Forests Graduate School of Agricultural and Life Sciences The University of Tokyo, 2004. Annual Report of Meteorological Observations in the University Forests. The University of Tokyo (January 2002-December 2002). The University Forests 43, 259-281.

The University Forests Graduate School of Agricultural and Life Sciences The University of Tokyo, 2005. Annual Report of Meteorological Observations in the University Forests. The University of Tokyo (January 2003-December 2003). The University Forests 44, 301-381.

The University Forests Graduate School of Agricultural and Life Sciences The University of Tokyo, 2006. Annual Report of Meteorological Observations in the University Forests. The University of Tokyo (January 2004-December 2004). The University Forests 45, 271-295.

The University Forests Graduate School of Agricultural and Life Sciences The University of Tokyo, 2007. Annual Report of Meteorological Observations in the University Forests. The University of Tokyo (January 2005-December 2005). The University Forests 46, 371-394.

Toba, T., Ohta, T., 2005. An observational study of the factors that influence interception loss in boreal and temperate forests. J. Hydrol. 313 , 208-220.

Tsukamoto, Y., 1998. Conservation of Forest, Water, and Soil. Asakura, Tokyo (in Japanese).

Vertessy, R.A., Watson, F.G.R., O’Sullivan, S.K., 2001. Factors determining relations between stand age and catchment water balance in mountain ash forests. Forest Ecol. Manage. 143, 13-26.

Ward, R.C., Robinson, M., 2000. Principles of Hydrology. McGraw-Hill, London.

Watanabe, T., Mizutani, K., 1996. Model study on micrometeorological aspects of rainfall interception over an evergreen broad-leaved forest. Agric. Forest Meteorol. 80, 195-214.

Yamada, T., Hibino, T., Araki, T., Nakatsugawa, M., 1995. Statistical characteristics of rainfall in mountainous basins. J. Hydraul. Coastal Environ. Eng. 527, 1-13 (in Japanese with English summary).

Yamamura, R., Nakano, H., 1985. Relationships between annual water losses and annual precipitation and altitude in forested watershed. J. Fac. Agric. Shinshu Univ. 22, 139-147 (in Japanese with English summary).

Yamazaki, T., Yabuki, H., Ohata, T., 2007. Hydrometeorological effects of intercepted snow in an eastern Siberian taiga forest using a land-surface model. Hydrol. Process. 21, 1148-1156.

Yamanoi, K., Ohtani, Y., 1992. Eddy correlation measurements of energy budget and characteristics of evapotranspiration above a hinoki stand. J. Jpn. Forest. Soc. 74, 221-228 (in Japanese with English summary). 